\title{
FAKTOR-FAKTOR YANG BERHUBUNGAN DENGAN PEMILIHAN METODE KONTRASEPSI JANGKA PANJANG (MKJP) DI DESA BANDORASA KULON KECAMATAN CILIMUS KABUPATEN KUNINGAN TAHUN 2021
}

\author{
Novita Sri Anggraeni, Mamlukah, Iding Budiman \\ STIKes Kuningan \\ anggraeninovitaa61@gmail.com
}

\begin{abstract}
Abstrak
Laju pertumbuhan penduduk Indonesia dari tahun ke tahun semakin meningkat. Pemerintah Indonesia telah mencanangkan berbagai program untuk menangani masalah kependudukan yang ada. Salah satu programnya dengan keluarga berencana nasional. Desa Bandorasa Kulon pengguna MKJP masih rendah yakni 23,42\% . Tujuan penelitian ini untuk mengetahui faktor-faktor yang berhubungan dengan pemilihan metode kontrasepsi jangka panjang (MKJP) di Desa Bandorasa Kulon Kecamatan Cilimus Kabupaten Kuningan Tahun 2021.

Jenis penelitian ini merupakan penelitian kuantitatif menekankan analisisnya pada datadata numerik (angka-angka) yang diolah dengan metode statistik dengan desain case control diambil sebanyak 70 akseptor KB. Metode pengumpulan data menggunakan data sekunder. Analisis univariat dalam bentuk tabel distribusi frekuensi dan analisis bivariat uji chi-square.

Hasil penelitian sebagian besar yang berumur $>30$ tahun memilih MKJP sebesar 60,7\%, sebagian besar yang memiliki paritas $>2$ memilih MKJP sebesar 63,6\%, semua yang memiliki akses yang sulit memilih MKJP sebesar 100\%, dan sebagian besar yang tidak memiliki dukungan suami memilih MKJP sebesar 78,6\%. Menunjukan bahwa adanya hubungan antara umur $(p$ value $=0,000)$, paritas $(p$ value $=0,013)$, akses ke tempat pelayanan $(p$ value $=0,005)$, dan dukungan suami ( $p$ value $=0,017)$, dengan pemilihan metode kontrasepsi jangka panjang (MKJP) di Desa Bandorasa Kulon Kecamatan Cilimus Kabupaten Kuningan Tahun 2021.

Ada hubungan signifikan antara umur, paritas, akses ke tempat pelayanan, dan dukungan suami dengan pemilihan metode kontrasepsi jangka panjang (MKJP) di Desa Bandorasa Kulon Kecamatan Cilimus Kabupaten Kuningan Tahun 2021.

Diharapkan dapat mengikuti program KB dengan memilih metode kontrasepsi yang sesuai serta terus menambah pengetahuan tentang pemilihan metode kontrasepsi.
\end{abstract}


JOURNAL OF HEALTH RESEARCH SCIENCE

VOL. 1 NO. 02, DESEMBER 2021

DOI: $\underline{10.34305 / J H R S . V 1 I 02.365}$
Ciptaan disebarluaskan di bawah

Lisensi Creative Commons Atribusi-

NonKomersial-BerbagiSerupa 4.0

Internasional.

Kata kunci : Umur, Paritas, Akses, Dukungan Suami, MKJP

\section{Pendahuluan}

Laju pertumbuhan penduduk Indonesia dari tahun ke tahun semakin meningkat, dapat dilihat data jumlah penduduk Indonesia tahun 2019 sebanyak 268.074.565 jiwa, meningkat dibandingkan jumlah tahun 2020 sebanyak 270.020.000 jiwa (BPS, 2020). Laju pertumbuhan penduduk ditentukan oleh tingkat kelahiran dan kematian, adanya perbaikan pelayanan kesehatan menyebabkan tingkat kematian penduduk rendah, sedangkan laju tingkat kelahiran tetap tinggi hal ini merupakan penyebab utama ledakan jumlah penduduk (Prawirohardjo, 2006). Laju pertumbuhan yang tinggi dapat berpengaruh terhadap kesejahteraan dan tingkat kehidupan penduduk (BKKBN, 2012). Tingginya angka kelahiran merupakan alasan utama diperlukannya pelayanan Keluarga Berencana (KB) (Kemenkes RI, 2014).

Pemerintah Indonesia telah mencanangkan berbagai program untuk menangani masalah kependudukan yang ada. Salah satu programnya dengan keluarga berencana nasional sebagai integral dari pembangunan nasional yang mempunyai tujuan ganda yaitu menunjukkan keluarga kecil bahagia sejahtera. Keadaan ini dapat dicapai dengan menganjurkan PUS untuk mengikuti Program KB (Perpres RI, 2010).

Menurut (BKKBN, 2011), jenis kontrasepsi berdasarkan lama efektivitasnya dibagi dua, yaitu MKJP dan non MKJP. Kebijakan program KB pemerintah saat ini lebih mengarah pada penggunaan kontrasepsi MKJP (IUD, Implant, MOW dan MOP). Pemerintah lebih menganjurkan MKJP berdasarkan pertimbangan non MKJP tidak ekonomis dan efisien dibandingkan MKJP (BKKBN, 2012). Dengan menggunakan MKJP selain akan menghemat biaya pengeluaran seseorang tidak perlu sering berkunjung untuk memperoleh alat kontrasepsi kembali serta cepat mengembalikan kesuburan (Winner et al., 2012).

Berdasarkan studi pendahuluan di UPTD P5A Kecamatan Cilimus, terdapat 8.110 PUS, 5725 pengguna aktif KB tahun 2020. Dari data didapat bahwa 1.909 akseptor $\mathrm{KB}$ memilih metode kontrasepsi jangka panjang (MKJP) dengan persentase 33,34\% dan 3.816 akseptor KB memilih metode kontrasepsi jangka pendek atau non MKJP dengan persentase $66,66 \%$. Desa 
JOURNAL OF HEALTH RESEARCH SCIENCE

VOL. 1 NO. 02, DESEMBER 2021

DOI: $10.34305 /$ JHRS.V1I02.365

Bandorasa Kulon memiliki 825 PUS, 525

pengguna aktif $\mathrm{KB}$, dari data didapat bahwa

137 pengguna $\mathrm{KB}$ aktif memilih metode kontrasepsi jangka panjang (MKJP) dengan persentase $23,42 \%$ dan 388 memilih metode kontrasepsi jangka pendek atau non-MKJP dengan presentase $76,58 \%$. Dapat diartikan bahwa masyarakat Cilimus terutama desa Bandorasa Kulon masih banyak yang memilih metode kontrasepsi jangka pendek (N-MKJP) dibanding metode kontrasepsi jangka panjang (MKJP). Metode kontrasepsi jangka Panjang (MKJP) adalah metode yang kontrasepsi yang dapat dipakai lebih dari dua tahun (Beaumont, 2012). Berdasarkan uraian diatas maka peneliti tertarik untuk meneliti Faktor-Faktor Yang Berhubungan dengan Pemilihan Metode Kontrasepsi Jangka Panjang (MKJP) di desa Bandorasa Kulon Kecamatan Cilimus Kabupaten Kuningan.

\section{Metode}

Penelitian ini dilakukan di Desa Bojong Kecamatan Cilimus Kabupaten Kuningan. Jenis penelitian ini merupakan penelitian kuantitatif menekankan analisisnya pada data-data numerik (angkaangka) yang diolah dengan metode statistika dengan rancangan case control. Penelitian ini untuk mengetahui Faktor-Faktor Yang
Ciptaan disebarluaskan di bawah

Lisensi Creative Commons Atribusi-

NonKomersial-BerbagiSerupa 4.0

Internasional.

Berhubungan Terhadap Pemilihan

Kontrasepsi Jangka Panjang di Desa

Bandorasa Kulon Kecamatan Cilimus

Kabupaten Kuningan.

Populasi dalam penelitian ini adalah seluruh akseptor KB di Desa Bandorasa Kulon Kecamatan Cilimus Kab Kuningan Tahun 2021 yang sebanyak 591 peserta KB aktif. Subjek dalam penelitian ini adalah semua kasus dan kontrol yang dipilih dengan perbandingan kasus dan kontrol 1:1. Kasus adalah akseptor $\mathrm{KB}$ yang memilih metode kontrasepsi jangka panjang, sedangkan kontrol adalah akseptor KB yang tidak memilih metode kontrasepsi jangka panjang atau memilih metode kontrasepsi jangka pendek. Berikut perhitungan desain case control dengan menggunakan rumus Lameshow didapat 70 sampel maka jumlah sampel pada kelompok kasus dan kontrol dibulatkan masing masing menjadi 35 sampel dengan proporsi 1:1 dan menambah $10 \%$ sampel, sehingga total sampel kelompok kasus dan kontrol sebanyak 70 sampel dengan sampel pada kelompok kasus sebanyak 35 dan sampel pada kelompok kontrol sebanyak 35 kasus.

Variabel bebas dalam penelitian ini adalah faktor umur, paritas, akses ke tempat pelayanan, dan dukungan suami. Variabel terikat dalam penelitian ini adalah pemilihan 
Ciptaan disebarluaskan di bawah

Lisensi Creative Commons Atribusi-

NonKomersial-BerbagiSerupa 4.0

Internasional. metode kontrasepsi jangka panjang (MKJP).

Pengumpulan data yang dilakukan peneliti adalah data sekunder dengan cara setelah peneliti mendapatkan izin penelitian dari STIKes Kuningan, peneliti meminta izin kepada Kepala UPTD P5A Kecamatan Cilimus Kabupaten Kuningan untuk memperoleh data dari PPKBD desa.

Tabel 1 Hubungan Umur, Paritas, Akses ke Tempat Pelayanan dan Dukungan Suami dengan Pemilihan Metode Kontrasepsi Jangka Panjang di Desa Bandorasa Kulon Kecamatan Cilimus Kabupaten Kuningan Tahun 2021

\begin{tabular}{|c|c|c|c|c|c|c|c|c|}
\hline \multirow{3}{*}{ Variabel } & \multicolumn{4}{|c|}{$\begin{array}{c}\text { Pemilihan Metode } \\
\text { Kontrasepsi }\end{array}$} & \multirow{2}{*}{\multicolumn{2}{|c|}{ Total }} & \multirow[t]{3}{*}{ P Value } & \multirow[t]{3}{*}{ QR (95\% CI) } \\
\hline & \multicolumn{2}{|c|}{ MKJP } & \multicolumn{2}{|c|}{$\begin{array}{l}\text { NON } \\
\text { MKJP }\end{array}$} & & & & \\
\hline & $F$ & $\%$ & $F$ & $\%$ & $\boldsymbol{F}$ & $\%$ & & \\
\hline \multicolumn{9}{|l|}{ Umur } \\
\hline $20-30$ & 1 & 7,1 & 13 & 92,9 & 14 & 100 & \multirow[t]{2}{*}{0,000} & 0,50 \\
\hline$>30$ & 34 & 60,7 & 22 & 39,3 & 56 & 100 & & $(0,006-0,408)$ \\
\hline \multicolumn{9}{|l|}{ Paritas } \\
\hline $1-2$ & 14 & 37,8 & 23 & 62,3 & 37 & 100 & \multirow[t]{2}{*}{0,013} & 0,348 \\
\hline$>2$ & 21 & 63,6 & 12 & 36,4 & 33 & 100 & & $(0,132-0,919)$ \\
\hline \multicolumn{9}{|l|}{$\begin{array}{l}\text { Akses Ke Tempat } \\
\text { Pelayanan }\end{array}$} \\
\hline Mudah & 28 & 44,4 & 35 & 55,6 & 63 & 100 & \multirow[t]{2}{*}{0,005} & - \\
\hline Sulit & 7 & 100 & 0 & 0 & 7 & 100 & & \\
\hline \multicolumn{9}{|l|}{ Dukungan Suami } \\
\hline Mendukung & 24 & 42,9 & 32 & 57,1 & 56 & 100 & \multirow[t]{2}{*}{0,017} & 0,205 \\
\hline Tidak Mendukung & 11 & 78,6 & 3 & 21,4 & 14 & 100 & & $(0,0510,815)$ \\
\hline
\end{tabular}

Sumber : Data Sekunder 2021

$$
\text { Berdasarkan tabel } 1 \text { menunjukan }
$$

bahwa hasil penelitian sebagian besar yang berumur $>30$ tahun memilih MKJP sebesar $60,7 \%$, sebagian besar yang memiliki paritas $>2$ memilih MKJP sebesar 63,6\%, semua yang memiliki akses yang sulit memilih MKJP sebesar 100\%, dan sebagian besar yang tidak memiliki dukungan suami memilih MKJP sebesar 78,6\%. Menunjukan bahwa adanya hubungan antara umur ( $p$ value $=0,000)$, paritas $(p$ value $=0,013)$, akses ke tempat pelayanan ( $p$ value $=0,005)$, dan dukungan suami ( $p$ value $=0,017)$, dengan pemilihan metode kontrasepsi jangka panjang (MKJP) di Desa Bandorasa Kulon Kecamatan Cilimus Kabupaten Kuningan Tahun 2021.

\section{Pembahasan}


JOURNAL OF HEALTH RESEARCH SCIENCE

VOL. 1 NO. 02, DESEMBER 2021

DOI: $10.34305 /$ JHRS.V1I02.365
Ciptaan disebarluaskan di bawah

Lisensi Creative Commons Atribusi-

NonKomersial-BerbagiSerupa 4.0

Internasional
1. Hubungan Umur dengan Pemilihan Metode Kontrasepsi Jangka Panjang (MKJP) di Desa Bandorasa Kulon Kecamatan Cilimus Kabupaten Kuningan Tahun 2021

Dengan demikian dapat dianalisis bahwa responden yang berumur 20-30 lebih banyak yang memilih metode kontrasepsi jangka pendek (Non-MKJP) karena merasa masih terlalu muda untuk menggunakan metode kontrasepsi jangka panjang (MKJP), pada responden umur 20-30 merupakan periode usia paling baik untuk melahirkan, dengan jumlah anak 2 orang dan jarak antara kelahiran adalah 2 sampai 4 tahun. Pada usia ini kontrasepsi yang diperlukan yaitu kontrasepsi yang mempunyai efektifitas dan reversibilitas yang cukup tinggi karena klien masih mengharapkan punya anak lagi, dapat dipakai 2 sampai 4 tahun yaitu sesuai dengan jarak kehamilan yang direncanakan, tidak menghambat produksi ASI.

Sedangkan dibandingkan responden yang memiliki umur $>30$ yang memilih metode kontrasepsi jangka panjang (MKJP) karena merasa sudah terlalu tua untuk memiliki anak lagi karena usia melahirkan yang lebih dari umur $>30$ tahun berisiko terhadap kesehatan. Periode umur responden $>30$ tahun, terutama diatas 35 tahun sebaliknya mengakhiri kesuburan terutama setelah mempunyai 2 orang anak. Menurut Hartanto (2004), seseorang yang semakin tua akan semakin bijaksana dan matang dalam memilih kontrasepsi. Sistem hormonal, struktur organ serta fungsi faal seseorang dipengaruhi oleh umur, sehingga kebutuhan dalam memilih metode kontrasepsi yang aman dan efektif (Kusumaningrum, 2009). Kontrasepsi yang diperlukan pada usia ini yaitu kontrasepsi yang mempunyai efektifitas yang sangat tinggi. Kegagalan menyebabkan terjadinya kehamilan yang beresiko tinggi bagi ibu dan bayi.

Berdasarkan hasil dari analisis uji statistik chi-square didapatkan $P$ value $=$ 0,000, sehingga dapat diputuskan bahwa adanya hubungan yang bermakna antara umur dengan pemilihan metode kontrasepsi jangka panjang (MKJP) di Desa Bandorasa Kulon Kecamatan Cilimus Kabupaten Kuningan tahun 2021. Hasil penelitian ini sejalan dengan penelitian yang dilakukan oleh Fitrianingsih \& Melaniani (2017) dan Suryanti (2019). Perilaku seseorang termasuk dalam pemilihan alat kontrasepsi dipengaruhi oleh umur. Peluang lebih kecil untuk menggunakan metode MKJP dimiliki oleh wanita usia muda dibandingkan dengan yang tua (Notoatmodjo, 2010). 
JOURNAL OF HEALTH RESEARCH SCIENCE

VOL. 1 NO. 02, DESEMBER 2021

DOI: $10.34305 /$ JHRS.V1I02.365
Ciptaan disebarluaskan di bawah

Lisensi Creative Commons Atribusi-

NonKomersial-BerbagiSerupa 4.0

Internasional
2. Hubungan Paritas dengan Pemilihan

Metode Kontrasepsi Jangka Panjang

(MKJP) di Desa Bandorasa Kulon

Kecamatan Cilimus Kabupaten Kuningan Tahun 2021

Berdasarkan hasil dari analisis uji statistik chi-square didapatkan $P$ value $=$ 0,031, sehingga dapat diputuskan bahwa adanya hubungan yang bermakna antara paritas dengan pemilihan Metode Kontrasepsi Jangka panjang (MKJP) di Desa Bandorasa Kulon Kecamatan Cilimus Kabupaten Kuningan Tahun 2021.

Dengan demikian responden yang memiliki anak 1-2 akan memilih metode kontrasepsi Non-MKJP karena kemungkinan ada keinginan untuk mempunyai anak lagi dibandingkan yang memiliki anak $>2$ yang memilih MKJP karena merasa sudah cukup untuk memiliki anak yang $>2$. Metode kontrasepsi jangka Panjang (MKJP) dapat mengurangi dan mencegah risiko kematian maternal terutama pada ibu yang memiliki jumlah anak lebih dari tiga. Pasangan suami istri yang memiliki anak banyak memiliki lebih besar kemungkinan untuk memulai kontrasepsi MKJP dibandingkan dengan pasangan yang mempunyai anak lebih sedikit (Fitrianingsih \& Melaniani, 2017).
3. Hubungan Akses ke Tempat Pelayanan dengan Pemilihan Metode Kontrasepsi Jangka Panjang (MKJP) di Desa Bandorasa Kulon Kecamatan Cilimus Kabupaten Kuningan Tahun 2021

Berdasarkan hasil dari analisis uji statistik chi-square didapatkan $P$ value $=$ 0,005, sehingga dapat diputuskan bahwa adanya hubungan yang bermakna antara akses ke tempat pelayanan dengan pemilihan Metode Kontrasepsi Jangka panjang (MKJP) di Desa Bandorasa Kulon Kecamatan Cilimus Kabupaten Kuningan Tahun 2021.

Akses ke tempat pelayanan pada dasarnya setiap orang mempertimbangkan jarak, waktu dan kemudahan transportasi untuk sampai di tempat pelayanan kesehatan. Bagaimanapun juga daerah yang bervariasi, transportasi yang beraneka ragam serta area yang sulit merupakan faktor penting dalam mendapatkan akses $\mathrm{KB}$ terutama pada daerah pedesaan.

4. Hubungan Dukungan Suami dengan Pemilihan Metode Kontrasepsi Jangka Panjang (MKJP) di Desa Bandorasa Kulon Kecamatan Cilimus Kabupaten Kuningan Tahun 2021

Berdasarkan hasil dari analisis uji statistik chi-square didapatkan $P$ value $=$ 0,017, sehingga dapat diputuskan bahwa ada 
JOURNAL OF HEALTH RESEARCH SCIENCE

VOL. 1 NO. 02, DESEMBER 2021

DOI: $10.34305 / \mathrm{JHRS} . \mathrm{V} 1 \mathrm{I} 02.365$
Ciptaan disebarluaskan di bawah

Lisensi Creative Commons Atribusi-

NonKomersial-BerbagiSerupa 4.0

Internasional. hubungan antara dukungan suami dengan dengan pemilihan metode kontrasepsi jangka panjang (MKJP) di Desa Bandorasa Kulon Kecamatan Cilimus Kabupaten Kuningan Tahun 2021.

Sebagaimana pendapat dari (Suparyanto, 2011), yaitu dalam melaksanakan Keluarga Berencana, dukungan suami sangat diperlukan. Karena penggunaan kontrasepsi merupakan tanggung jawab bersama pria dan wanita sebagai pasangan, sehingga metode kontrasepsi yang dipilih mencerminkan kebutuhan serta keinginan suami dan istri. Suami dan istri harus saling mendukung dalam penggunaan metode kontrasepsi karena keluarga berencana dan kesehatan reproduksi bukan hanya urusan pria atau wanita saja.

Dukungan suami sangat berpengaruh besar dalam pengambilan keputusan menggunakan atau tidak dan metode apa yang akan dipakai (Samira \& Yuniawati, 2013). Karena tanpa adanya dukungan dari suami, rasa nyaman untuk menggunakan kontrasepsi tidak akan didapatkan, metode kontrasepsi tidak dapat dipaksakan pasangan suami istri harus bersama memilih metode kontrasepsi yang terbaik, saling kerjasama dalam pemakaian, membiayai pengeluaran kontrasepsi, dan memperhatikan tanda dan bahaya.

\section{Kesimpulan}

1. Sebagian besar karakteristik umur responden $>30$ Tahun sebanyak 56 responden (80\%), paritas akseptor KB 1-2 sebanyak 37 responden (52,9\%), akses ke tempat pelayanan mudah sebanyak 63 responden (90\%), dukungan suami sebanyak 56 responden $(80 \%)$, dan Sebagian responden memilih metode kontrasepsi jangka panjang (MKJP) sebanyak 35 responden $(50 \%)$ sebagian memilih metode kontrasepsi jangka pendek (Non-MKJP) sebanyak 35 responden (50\%) di Desa Bandorasa Kulon Kecamatan Cilimus Kabupaten Kuningan tahun 2021

2. Terdapat hubungan antara umur dengan pemilihan Metode Kontrasepsi Jangka Panjang (MKJP) di Desa Bandorasa Kulon Kecamatan Cilimus Kabupaten Kuningan Tahun 2021 dengan nilai $P$ value $=0,000$ atau kurang dari 0,05.

3. Terdapat hubungan antara paritas dengan pemilihan Metode Kontrasepsi Jangka Panjang (MKJP) di Desa Bandorasa Kulon Kecamatan Cilimus Kabupaten Kuningan Tahun 2021 dengan nilai $P$ value $=0,031$ atau kurang dari 0,05 . 
JOURNAL OF HEALTH RESEARCH SCIENCE

VOL. 1 NO. 02, DESEMBER 2021

DOI: $10.34305 /$ JHRS.V1I02.365
Ciptaan disebarluaskan di bawah

Lisensi Creative Commons Atribusi-

NonKomersial-BerbagiSerupa 4.0

Internasional.
4. Terdapat hubungan antara akses ke tempat pelayanan dengan pemilihan Metode Kontrasepsi Jangka Panjang (MKJP) di Desa Bandorasa Kulon Kecamatan Cilimus Kabupaten Kuningan Tahun 2021 dengan nilai $P$ value $=0,005$ atau kurang dari 0,05.

5. Terdapat hubungan antara dukungan suami dengan pemilihan Metode Kontrasepsi Jangka Panjang (MKJP) di Desa Bandorasa Kulon Kecamatan Cilimus Kabupaten Kuningan Tahun 2021 dengan nilai $P$ value $=0,017$ atau kurang dari 0,05 .

\section{Saran}

Bagi pengguna $\mathrm{KB}$ diharapkan dapat mengikuti program $\mathrm{KB}$ dengan memilih metode kontrasepsi yang sesuai serta terus menambah pengetahuan tentang pemilihan metode kontrasepsi.

Bagi tempat penelitian diharapkan terus meningkatkan masyarakat agar menggunakan $\mathrm{KB}$ dan diharapkan dapat memberikan informasi terkait faktor faktor yang berhubungan dengan pemilihan metode kontrasepsi.

Bagi tenaga kesehatan diharapkan dapat melakukan penyuluhan untuk memberikan informasi kepada akseptor KB tentang program keluarga berencana sebagai pengetahuan dari tenaga kesehatan masyarakat.

\section{Daftar Pustaka}

Beaumont, R. (2012). An Introduction To Statistics Correlation. Access via Internet : http://www. floppybunny. org/robin/web/virtualclassroom

BKKBN. (2011). Analisis Lanjut 2011. Faktor Yang Memengaruhi Penggunaan MKJP di Enam Wilayah Indonesia.

BKKBN. (2012). Informasi Pelayanan Kontrasepsi.

BPS. (2020). Hasil Sensus Penduduk 2020. https://www.bps.go.id/pressrelease/20 21/01/21/1854/hasil-sensus-penduduk2020.html

Fitrianingsih, A. D. R., \& Melaniani, S. (2017). Faktor Sosiodemografi yang Memengaruhi Pemilihan Metode Kontrasepsi. Jurnal Biometrika Dan Kependudukan, $\quad 5(1), \quad 10$. https://doi.org/10.20473/jbk.v5i1.2016 .10-18

Hartanto, H. (2004). Keluarga berencana dan kontrasepsi.

Kemenkes RI. (2014). Profil Kesehatan Indonesia Tahun 2013 - Kementrian Kesehatan Indonesia. In V. Sitohang, D. Budijanto, B. Hardhana, \& T. A. Soenardi

Pusdatin.Kemenkes.Go.Id.

(Eds.),

Kementerian Kesehatan Republik Indonesia Jalan HR. Rasuna Said Blok X-5 Kav 4-9, Jakarta 12950.

Kusumaningrum, R. (2009). Faktor-Faktor Yang Mempengaruhi Pemilihan Jenis Kontrasepsi Yang Digunakan Pada Pasangan Usia Subur (Factors 
JOURNAL OF HEALTH RESEARCH SCIENCE

VOL. 1 NO. 02, DESEMBER 2021

DOI: $10.34305 /$ JHRS.V1I02.365

Influencing The Choice Of Contraception Type Used By Fertile Aged Couple). Medical Faculty.

Notoatmodjo, S. (2010). Ilmu perilaku kesehatan.

Perpres RI. (2010). Peraturan Presiden Republik Indonesia Nomor 62 Tahun 2010 Tentang Badan Kependudukan Dan Keluarga Berencana Nasional. Basis Data Kemenkumham, 1-14. http://www.kemenkumham.go.id/attac hments/article/140/Inpres-03-03.pdf

Prawirohardjo, S. (2006). Buku Acuan Nasional: Pelayanan Kesehatan Maternal dan Neonatal. In A. B. Saifuddin \& G. Adrianz (Eds.), Yayasan Bina Pustaka Sarwono Prawirohardjo. Yayasan Bina Pustaka Sarwono Prawirohardjo. https://opac.perpusnas.go.id/DetailOpa c.aspx?id $=508530$

Samira, S. A., \& Yuniawati, C. (2013). Faktor-Faktor Yang Berhubungan
Ciptaan disebarluaskan di bawah

Lisensi Creative Commons Atribusi-

NonKomersial-BerbagiSerupa 4.0

Internasional.

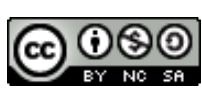

Dengan Pemilihan Metode Kontrasepsi

Oleh Pus Di Desa Peunyerat Kecamatan Banda Raya Banda Aceh.

Sekolah Tinggi Ilmu Kesehatan U'budiyah Program Studi Diploma Iv Kebidanan Banda Aceh.

Suparyanto, R. (2011). Wanita usia subur dan kanker payudara. Di Akses Pada Tanggal, 3 November 2021.

Suryanti, Y. (2019). Faktor-Faktor Yang Berhubungan Dengan Penggunaan Metode Kontrasepsi Jangka Panjang Wanita Usia Subur. Jambura Journal of Health Sciences and Research, 1(1), 20-29.

https://doi.org/10.35971/jjhsr.v1i1.179 5

Winner, B., Peipert, J. F., Zhao, Q., Buckel, C., Madden, T., Allsworth, J. E., \& Secura, G. M. (2012). Effectiveness of long-acting reversible contraception. New England Journal of Medicine, 366(21), 1998-2007. 